\title{
Contents
}

List of Figures vii

Map of Trinidad viii

Acknowledgments ix

I. Introduction 1

2. Being a Factory the Signature Way 25

3. Raced and Emplaced: Signature Fashions Workers $\quad 51$

4. "Is We Own Factory": Thiefing a Chance on the Shop Floor $\quad 87$

5. "Keeping Up with Style": The Struggle for Skill 111

6. "Use a Next Hand": Risk, Injury, and the Body at Work 143

7. "Kidnapping Go Build Back We Economy": Criminal

Tropes in Neoliberal Capitalism 173

8. Conclusion 195

References 205

Index 225 


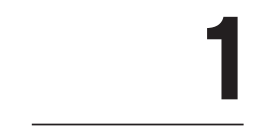

Introduction

A region literally born out of colonialism, export industrialization, and capitalism broadly speaking, for the Caribbean what we now analyze as globalization, modernity, and here, neoliberalism, have arguably been integral to the region's very self-definition. These political-economic systems have

insinuated themselves deeply into some of the region's well-established cultural contours, and these, in turn, have given the political-economic systems a vernacular form.

- Carla Freeman, "Neoliberalism, Respectability, and the Romance of Flexibility in Barbados"

Rebecca, you wanted to know what is "thiefing a chance?" I'm going to tell you. Some would say it is stealing. Some would say. But some would say it's what you could do for yourself. - Glenda, Signature Fashions worker

It is early morning at Signature Fashions, but work in the factory is already well under way. Throughout the stitching section, workers are busy sewing the latest line of garments bound for Signature's branded stores in Trinidad, Tobago, and throughout the Caribbean region. Kimberly is quietly at work on the hemming machine, passing T-shirt after T-shirt under its double needles, leaving two neat rows of stitching on the bottom of each garment. As 
soon as Cissy, the production manager, leaves the shop floor to enter the cutting room, Kimberly stops working and leans forward in her chair. She hisses at Gita, sitting at the straight-stitch sewing machine in front of her.

"Ssssssst," she says. Gita looks over her shoulder at Kimberly. "If I give you a shirt, you could put a pocket on it and keep your stories straight?"

"Sure," Gita says, turning back to her work. I don't see Kimberly pass Gita the shirt and pocket, but I expect that she will do so later in the morning, now that Gita has agreed to "thief a chance" for her. For now, the shirt-an exact copy of the brand-name garments the workers have been laboring over all week - rests in a black plastic garbage bag hanging beneath Kimberly's machine. With the help of fellow workers at nearly every stage of the production process, by the end of the day Kimberly will have completed for herself a precise replica of the shirts that will appear in Signature's stores in time for Easter. She will smuggle it out of the factory either underneath her clothes or stashed in the bottom of her handbag, folded into a tight ball and stitched inside a scrap of cloth to look like a simple, homemade pincushion.

This is a book about life in a garment factory in Trinidad, West Indies. Its ethnographic moment is more than ten years after an International Monetary Fund (IMF)-backed program of liberalization began opening national trade barriers to readymade garments from abroad - an act that crippled the local industry in the face of intense global competition, transformed worker entitlements and expectations, and also presented new economic opportunities for engaging the global market. From the vantage of the shop floor, I examine the lived experience of economic restructuring. Moving beyond approaches that conceptualize factory workers as subjects who are mostly acted upon, I pay special attention to workers' attempts to exploit the interstices of new labor configurations through illicit and informal uses of the factory-practices they collectively dub "thiefing a chance." Despite the intense social coordination involved in "thiefing," workers describe it as a personal, individualistic enterprise rather than a form of collective resistance to workplace hegemony. Thiefing, in other words, is "what you could do for yourself." I suggest therefore that thiefing a chance is not only a material practice; it is also a potent metaphor for how Trinidadian garment workers have confronted the ambivalent returns of the neoliberal era. By making and taking furtive opportunities, workers embrace a vision of themselves as enterprising subjects while actively complying with the competitive demands of a 
new economic order. An examination of the relationship among these (mis) uses of the factory, the labor process, and the subjectivities of the workforce reveals that thiefing is surprisingly "productive" in all kinds of ways.

Trade liberalization has created a new, global manufacturing landscape in which particular geographic regions now dominate garment production for the world market while other parts of the globe are considered economically untenable as clothing producers, even for domestic consumption. Recent years have seen the ascendance of China, Bangladesh, and India in the export-oriented production of garments and an associated decline of apparel manufacturing in North America, Europe, and the Caribbean (Gereffi and Frederick 2010; Lu 2013; Nordas 2004; Rivoli 2005; Frederick and Staritz 2012). Academic analyses often describe these processes in terms of the "winners" and "losers" of globalization. Yet I present a more complex and nuanced picture of a diverse, variegated, and tenacious local industry in Trinidad that has endured despite global trade liberalization in the form of small and medium-sized factories, illegal sweatshops, seamstresses' and tailors' workshops, and many hundreds of women stitching clothing for friends, family, and clients at home. These heterogeneous sites are connected to each other by the bodies of women who pursue employment, skill acquisition, and illicit enterprises in and through multiple locations. In its ethnographic specificity, this book examines what Neil Brenner and Nik Theodore (2002) call "actually existing neoliberalism," the complex, messy, and contingent ways an economic doctrine of liberalization, privatization, and competition becomes lived as everyday experiences. This neoliberalism is as much constituted through the ways in which people engage and invest in it as by state policies that institute it as a regime of economic governance.

\section{The Paradox of Flexibility}

I spent nine of my fifteen months of fieldwork in Trinidad cutting, stitching, and packaging designer-label clothing alongside workers like Kimberly and Gita. The factory, which I call "Signature Fashions," produces contemporary, high-fashion clothing for the Eastern Caribbean market. Signature Fashions has survived the vagaries of trade liberalization by cultivating a distinctive brand name for its high-fashion garments with a quick turnaround from 
design and production to retail. As I conducted participant observation in the Signature Fashions factory, two things became quickly apparent to me that later shaped much of my interpretation of garment workers' experiences in Trinidad. First, although Signature Fashions produces a constantly changing, retail-driven product with a short production cycle, the factory's manufacturing process is modeled on the assembly line of classic Fordism-designed for the mass production of standard products by narrowly specialized workersrather than on a "flexible," dynamic system of continual learning that would seem to suit the production of high-end garments. Workers at Signature Fashions were given little formal training and were not encouraged to innovate, to make decisions, or to problem-solve on the shop floor. Instead, workplace discipline promoted quiet acquiescence to supervisors' demands, invariably evoking the "boss lady" and "boss man" (the company's co-owners) as distant figures of central authority.

Signature Fashions, then, has a fundamental contradiction within its production process: the apparent incompatibility of a rigid, old-guard manufacturing system and a market-adaptive product. How, I wondered, did such flexible goods issue from a seemingly inflexible system? This is a question I call the "paradox of flexibility." The second thing visible to me on the shop floor were the multiple ways workers took advantage of the brief moments when their supervisors' backs were turned to work on illicit projects. Many of the workers maintained their own small-scale businesses in the evening, designing and stitching clothing for friends and neighbors at home. Some workers would copy Signature patterns for their clients by cleverly placing the cut pieces of a garment onto newspaper and tracing the shapes with a pen. ("Have to keep up with style if you sew for people," a worker named Antoinette once whispered to me as I watched her copy the pattern for a designer shirt in this way.) Workers would sometimes bring garments for their clients into the factory to give their homemade items a professional finish. Each of these activities was quietly described as thiefing a chance-a Trinidadian phrase that means taking an illicit opportunity for a small amount of personal gain. In its most sophisticated form, thiefing a chance also meant using company materials and machines to produce exact copies of the designer-label clothing as it came down the line. Workers managed the production of these garments by acquiring fabric from the cutting room and covertly enlisting co-workers to stitch for them during the normal workday. 
The clothing produced on this clandestine assembly line would be smuggled home and worn at parties and other social events far away from the factory.

What seemed at first to be two interesting but unrelated features of shopfloor life-the incongruous rigidity of a factory requiring flexible production and workers' practices of thiefing a chance-have proven, with analysis, to be thoroughly entwined. Signature Fashions did churn out a constantly changing, market-responsive product. Yet this productive flexibility was not achieved through formal training and learning, workplace democracy, or any of the other managerial techniques that might be valued by a vertically integrated firm in an era of "flexible specialization" (Piore and Sabel 1984). Instead, in a hierarchical, Fordist organizational structure, flexibility became instituted in informal and unacknowledged ways: first, through a periodic intensification of labor and second, through a range of illicit activities workers quietly pursued on their own. When workers thief a chance, they skill themselves up for new sewing tasks - training themselves in a factory that refused to train them-and by managing the production of their own items, workers become invested in the smooth functioning of the entire manufacturing process. Through thiefing (not despite it), workers complied with management's unspoken instructions to become a flexible, self-motivating labor force.

My ethnography therefore contributes to scholarship that troubles conventional readings of "the factory" as a stable institution by emphasizing the intense and covert linkages between formal and informal registers of production. By analyzing how workers' everyday tactics intersect with the strategies of their employers, I show the Signature Fashions factory to be a material and social space in which a wide range of projects, plans, and desires becomes aligned and misaligned, at some moments in deep harmony and at others in rancorous conflict. Industrial ethnographies often highlight the disjuncture between the ideologies and practices of factory production, revealing hidden dependencies between formal and informal labor (Bolles 1996; De Neve 2005; Mollona 2009), the roles of kinship, gender, and racialized processes of subject-making in the manufacturing process (Fernandes 1997; Kim 2013; Lamphere 1987; Salzinger 2003; Yelvington 1995; Westwood 1984), and the importance of sentiments like desire in motivating laborers and capitalists alike (Cross 2009; Freeman 1998; Mills 1999; Shah 2006; Yanagisako 2002). I extend this tradition by examining the productive power of informal, unofficial, and illicit activities by workers on the shop floor, emphasizing the 
variability of their effects and how they frequently diverge from the intentions of the actors behind them.

Flexible production at Signature Fashions has been achieved less by design in response to the pressures of global free trade than by a paradox of authoritarian discipline and expectations of adaptability that garment workers daily resolve through illicit work practices. My analysis suggests a new reading of "the factory" as a far more accidental, in-deliberate, and serendipitous entity than is usually depicted. The factory here is approached not as a fixed, bounded, or unitary institution but instead as a social and material assemblage constituted through authorized and unauthorized action, acknowledged and unacknowledged interests, planned and unintended consequences. I emphasize that the interests of capitalists and workers are not always known to them and that a successful company can sometimes be sustained as much by the chance alignment of desires as by deliberate planning and activity.

This argument builds upon Sylvia Yanagisako's contention that analyses of economic motivation have been limited by an emphasis on goals and values as mental constructions over the embodied desires that also inspire human action. In her ethnography of the reproduction and maintenance of a capitalist class across several generations in the Italian silk-weaving industry, Yanagisako (2002:7-II) describes an internally differentiated bourgeoisie motivated as much by "sentiments," like the patriarchal desire for filial succession, as by a rational interest in profit maximization. She demonstrates that these sentiments constitute a force of production because they inspire particular forms of capitalist action, shaping the development of the silk industry in ways that are rarely acknowledged. I share with Yanagisako (ibid.:9) a rejection of dichotomizing approaches that separate "instrumental" from "affective" economic motivations. But by focusing on both employers and workers, I show how they bring competing needs to the factory that fall into and out of alignment with one another on the shop floor. My emphasis on the productive nature of these alignments reveals the sometimes incidental nature of capitalist success.

\section{Global Capitalism’s Long Embrace}

This book is concerned with Trinidad, an island of I,84I square miles with approximately I million inhabitants, located seven miles from the Venezuelan 
coastline (ILO 2004; see figure I.I). Although Trinidad is joined with its neighboring island, Tobago, in the parliamentary Republic of Trinidad and Tobago, I follow the anthropological practice of treating the two islands separately. Trinidad has always been shaped by the vicissitudes of global capitalism; it can even be said that "Trinidad has been the creation of the global economy" (Miller 1994a:24). "Discovered" by Christopher Columbus in I498, Trinidad was colonized by Spain, though neglected by the colonial power until the late eighteenth century. At that time, French slave owners fleeing political turmoil in the French West Indies were invited to settle the island and began cultivating sugar, cocoa, and cotton with enslaved African labor. Britain seized Trinidad in 1797 , and the island remained a British colony until its political independence in 1962 (Brereton I981:I-33, 222). After the emancipation of the slaves in 1838 , indentured labor was "invited" from elsewhere in the British Empire, particularly India. The indentured Indian workers introduced to the island between I 845 and 1917 have given the society its diverse, "plural" character, as have the many migrants of European, Chinese, Venezuelan, Syrian, Lebanese, and African origin (England 2008:26).

Trinidad's slave plantations supplied the raw materials to fuel European industrialization; today, the country is principally a producer of oil and natural gas for the world market. Following an oil boom in the 1970s, Trinidad experienced a prolonged recession that culminated in three structural adjustment programs with the IMF and the World Bank in the late I980s and early I990s (Hilaire 2000). These agreements marked a shift from a state-controlled to a market-driven economy and entailed cutting public spending in exchange for technical and financial aid to revive the economy; the privatization of state-owned enterprises; a devaluation and floating of the national currency; withdrawal of most subsidies and price controls on food, medicine, and utilities; a reduction of the civil service through early retirement and layoffs; and the dismantling of trade barriers that had shielded local industry from global competition (Bynoe 2000; Henry and Williams I99I; ILO 2004; Riddell 2003; USDS 200I; WTO 1998).

Under the new terms of neoliberal governance, tariff and licensing protections would be mostly shed in favor of free trade (Ramsaran 1992; Sergeant and Forde 1992). The restructuring of Trinidad's garment sector began with a temporary replacement of quantitative import restrictions with "import surcharges," which were then gradually removed (Hilaire 2000:23). As a 


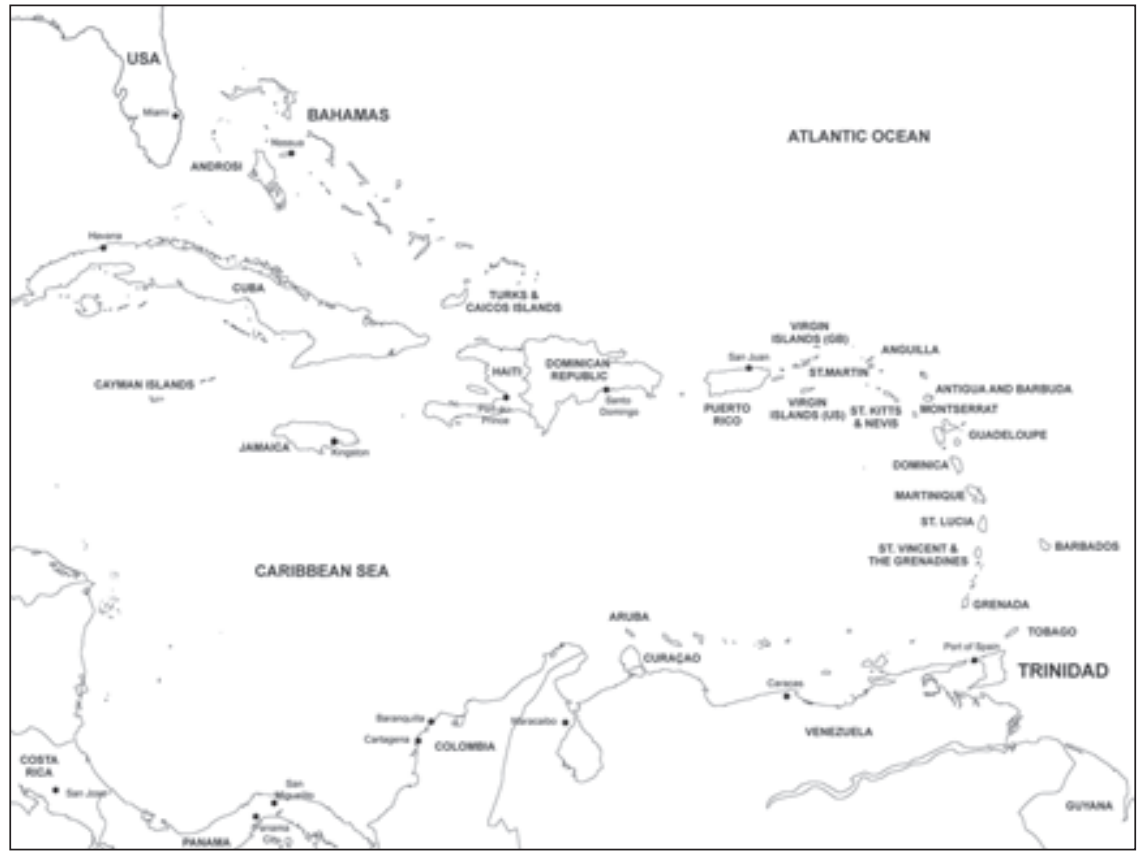

Figure I.I. Map of Trinidad and the Caribbean region (map by Adam Howse)

member of the Caribbean Community (CARICOM), Trinidad adopted policies that would harmonize trade within the region. ${ }^{1}$ By 1998, import duties of 45-50 percent on garments produced outside Trinidad had been reduced to o percent within the free trade area of CARICOM and to 20 percent on non-CARICOM goods (World Bank 2009; USDS 200I).

As liberalization policies began to take hold, many local companies found themselves unable to compete with the quality and price of clothing newly arriving from overseas. As one former factory owner told me, trade liberalization "was the death of the local garment industry. There is no way [we] could compete with goods coming directly out of China." Manufacturers of commodity garments like T-shirts and trousers have been the most vulnerable; although the lowering of tariffs on non-CARICOM imports to 20 percent appears to offer continuing protection to Trinidadian producers exporting to the regional market, it has been insufficient to offset the comparative advantage of low wages and economies of scale that benefit large Asian suppliers (Rahman et al. 2008; World Bank 2009). 
Between 1990 and 2000, Trinidad's garment manufacturing workforce declined 42 percent, although official statistics mask the extent to which garment workers' livelihoods have moved into an informal sector of sporadic employment and domestic needleworking where their labor remained uncounted (CSO 2003:27). The country's dependency on imports to meet basic needs meant that the devaluation of the Trinidad and Tobago dollar raised the cost of living (Hilaire 2000; Riddell 2003). With the doubling of food prices between 1995 and 2005 (Manning 2005), even workers with fulltime employment in minimum-wage factories like Signature Fashions frequently supplemented their income by sewing at home.

During the course of my fieldwork and in the months and years since, I have come to see thiefing a chance as a central idiom for how garment workers in Trinidad have coped with the demands of the neoliberal era. Since the I990s, garment workers have witnessed the withdrawal of both state and trade-union interest in their welfare in the factories and an increasing need to look after themselves in everything ranging from pay disputes to occupational injury. This period has also seen a yearning among Trinidadians for brandname clothing carrying markers of style and status that are central to modern self-making in this island context (Miller 1994a). Signature Fashions workers maneuver within the material conditions of the local environment, seeking not only economic survival but also the opportunity to undertake culturally oriented projects such as producing, wearing, and gifting high-status clothing. "Thiefing a chance" is a resolutely Trinidadian phrase. It is part of a wider cultural discourse about how an individual can best "get on" in a constantly changing and competitive economic arena. These kinds of discourses date back to at least the slave era, when trickster tales encoded culturally accepted survival strategies throughout the Black Atlantic (Andrews and Gates 1999; Harris 1995; Roberts 1989). New World slavery demanded modes of coping marked not only by self-reliance and resourcefulness but also craftiness and guile. This cultural complex, both practical and stylistic, is celebrated in local narratives that recast ex-slaves as not just survivors but heroes of their own history. Katherine Browne's (2004) examination of illicit economic practices in Martinique shows how widespread, off-the-books ventures in building, entrepreneurship, and small-scale trading are not only profitable for participants but also serve a cultural purpose in enhancing the esteem of those who participate in them, known locally as débrouillards. Martiniquans pursue 
off-the-books economic activities (which Browne calls "creole economics") to achieve financial autonomy despite the law while at the same time satisfying their desire for a self-reliant economic selfhood. Creole economics contains the pleasures of both risk taking and social recognition, although for men becoming a débrouillard is concerned with being one's own boss whereas women emphasize the need to escape dependency on men.

Browne shows that creole economics valorizes a disregard for the law as long as it is carried out with creativity, cunning, and flair. She locates the roots of this moral code in the slave period, considering it an adaptation to the privations and humiliations of the slavery experience (ibid.:I20-22). Débrouillardism therefore embodies a defiant strain of creole culture that has always run counter to the European-derived values of respectability and deference to social hierarchy (Wilson 1973:9). However, by tracing a historical genealogy that emphasizes cultural continuity, Browne overlooks the fact that débrouillardism also represents the entrepreneurial spirit that neoliberalism now enshrines as a foremost value. We live in the age of the daring individual, when success means making and taking opportunities for yourself. In this book I argue that there has been a remarkable convergence between the forms of subjectivity promoted by neoliberalism and the economic self hood embodied in practices like thiefing a chance. As Carla Freeman $(2005,2007)$ has observed, this reflects the ways in which a neoliberal economic order confers new respectability on old Caribbean cultural mores by recasting creole values as virtues rather than vices. My aim is to ethnographically document this convergence and consider what it means for workers and workplaces in Trinidad.

\section{A Neoliberal Factory}

How can we account for the similitude between the values of neoliberalism and thiefing a chance? Sidney Mintz might argue that they both possess shared Caribbean origins. He observes that the region has been "global" since the fifteenth century, that its colonial position gave rise to the West as we know it, and that the slave plantations - with their technical features, hierarchical structures, and adherence to strict time disciplines-were prototypical industrial factories (Mintz 1996:295, 1998; Williams 1994). The Caribbean is not a non-Western outpost recently penetrated by international capitalism. 
Rather, it is where modern capitalism found early and brutal expression and where new techniques of production, surveillance, and the transmutation of persons into mechanistic laborers formed a profitable foundation for New World economy and society.

An interpretation of the Caribbean as capitalism's cradle explains why globalization has been uniquely experienced in the region not as the "radical reversal of relationships of property, culture, and power" but instead as "the extension of already established relationships ... a realignment rather than a rupture" (Robotham 1998:308 [original emphasis]). According to Jeffrey Mantz (2007), the region's centuries-long imbrication in the world market has produced economic subjectivities that render Caribbean people particularly able, confident, and uncomplaining in their encounters with neoliberal capitalism. Writing about the resourcefulness of female agricultural traders ("hucksters") in Dominica, Mantz portrays their entrepreneurial savvy as part of a flexible economic disposition culturally autochthonous to the region. Gina Ulysse makes a similar observation about female informal importers and market traders in Jamaica. She describes how the women have confronted each restriction on their trade, such as increasingly strict customs policies, as a challenge to overcome. As one informant proclaimed: "There isn't a foundation that don't have a crack in it ... We will find it and we will go right through it" (Ulysse 2007:I).

Trinidadian women like the ones I describe, sitting at rows of sewing machines, toiling beneath fluorescent lights, seem to fulfill the image of generic victims of contemporary capitalism: hardworking, poorly paid, and with little ability to influence the conditions of their employment. Yet such an interpretation represents a limited approach to women's economic agency of the kind criticized by feminist anthropologists in recent years (Lynch 2007; Mills 1999; Ngai 2005; Rofel 1999). Shop-floor ethnographies reveal not only the pervasive and powerful ways workplaces act upon the subjectivities of women workers-subtly disciplining them to become the "docile bodies" of production envisioned by Michel Foucault (1979) - but also how these processes are confronted, resisted, and transformed by those enmeshed in them. Because every economic system presents not just constraints on agency but also opportunities for action, we must resist unidirectional analyses that would portray neoliberal globalization as something that is simply done "to" Caribbean women (Freeman 200I). An ethnographic approach means not 
succumbing to a view of Caribbean women as perennial victims or as the rational actors of neoclassical economic fantasy; rather, it asks us to consider how women interpret and act upon their world in big and small ways and with what effects.

Kevin Yelvington's study of a Trinidadian factory showed how the proliferation of low-end assembling industries in the global South required their insertion into the cultural, political, and economic matrices that already existed in places like Trinidad (Yelvington 1995). On the shop floor, management mobilized social hierarchies of race, class, and gender derived from the plantation economy to fragment the workforce into separate occupational niches. This move successfully divided workers' interests because they comported with false but commonsensical notions that different races and genders were predisposed to certain types of work. Just as the planter elite once promulgated negative stereotypes of African and East Indian workers to wedge apart their shared class interests, Yelvington shows how these strategies are most successful when groups internalize the unfavorable portrayals of themselves and each other (ibid.:50, 65; Munasinghe 200r:66). The Trinidadian shop floor therefore cannot be understood except in relation to its capitalist history and how that history articulates with local social categories and identities.

For Trinidadian garment workers, the neoliberal turn has meant new challenges but not an upending of life as they knew it before. They have greeted these challenges with a sense of familiarity rather than alarm. The patience, resilience, and readiness to adapt to new labor regimes that have long helped Caribbean women survive also make them exemplary "flexible" economic actors for the neoliberal era. ${ }^{2}$ I show in this book that the prevalence of these qualities in the workforce represents an important but neglected reason why Trinidad's garment industry has endured since trade liberalization. In probing how an institutional reliance on the flexibility of labor ultimately disadvantages workers in a context of waged employment, I ask to what extent garment workers have been made accomplices in their own exploitation.

\section{Illicit Acts and Questions of Agency}

By placing an analysis of the illicit at the heart of my study, this book explores the role of unsanctioned work practices in a neoliberal labor process. The 
anthropological literature contains abundant examples of theft, poaching, pilfering, side production, and game playing among industrial workers and other types of employees (Anteby 2008; Burawoy 1985; Haraszti 1978; Mars 1982; Yelvington 1995). Scholars have demonstrated that illicit and informal activities on the shop floor should be considered neither deviant nor ancillary to production but rather must be analyzed in relation to official work processes.

Michael Burawoy (1979) famously described workers in an American machine shop who attempted to gain control over their work through shopfloor games that maximized the financial returns of piece-rate payment without disrupting the ability of others to do the same. Approaching work as a game, employees assessed the likelihood of being able to exceed the piece rate ("making out"). Workers who faced backbreaking piece rates responded by choosing not to make the quota, satisfying themselves instead with the guaranteed-minimum base pay; those who were assigned easy-to-achieve piece rates disciplined themselves to keep production below the maximum they could produce, believing that if they overproduced, management would simply recalibrate the rates (ibid.:57). Although making out required cooperation and the enforcement of shared norms, it also had the unintended effect of individualizing workers and enjoining them to work harder. For Burawoy, what is most important is that through these games, workers not only participate in the appropriation of the surplus value of their labor; they also participate in obscuring this surplus value extraction. Through making out, workers gain a sense of mastery and autonomy over their work while at the same time consenting to their own exploitation. This element of consent (which obviates coercion) gives such casual "games" a pernicious effect by reconfiguring workers' internal motivations.

In examining thiefing a chance at Signature Fashions, it is important to consider not simply the intentions of workers as active agents in production but also the effects of their illicit practices, both on themselves and on the labor process. Copying garments on the shop floor may act as a strain on the manufacturing process, but, as Burawoy suggests, it may also operate as a lubricant to the smooth functioning of production. We cannot assume prima facie that illicit acts are inimical to the interests of employers but instead must examine them in the context of material and ideological struggles. Over the past three decades, James Scott's concept of "everyday resistance" has rejuvenated a 
Gramscian analytic that frames the relationship between unsanctioned activities and the everyday politics of labor in terms of accommodation and resistance (Scott 1985, 2005). Scott described Malaysian peasant laborers' secret and uncoordinated acts of pilfering, gossiping, foot dragging, slander, and evasion not as spontaneous though inconsequential transgressions but instead as evidence of a latent revolutionary consciousness that continually critiqued the prevailing economic and political order. Gossiping and joking about the dominant classes demonstrated the ability of subordinate groups to penetrate hegemonic portrayals of the world; pilfering from landowners without remorse shows the persistence of local moral economies. For Scott, these examples of "everyday resistance" provide evidence that class consciousness can reside behind even the most convincing mask of compliance.

Yet if we are primed to theorize workers' unsanctioned activities as resistance to the exploitative conditions in which they labor, we might be surprised to discover that Signature Fashions workers insist on a depoliticized interpretation of thiefing a chance. Workers do not describe thiefing as a form of redistributive justice and refuse to justify it as compensation for the inequity in earnings between themselves and their employers. Instead, the factory is encountered as a resource containing materials, machines, and know-how that the cunning individual uses for her own purposes. Thiefing a chance is rendered morally acceptable precisely because its participants do not define the practice as taking from employers. Workers who thief a chance see themselves as seizing an opportunity that has fleetingly arisen in their midst. Like the débrouillards described by Katherine Browne, they pride themselves on doing so with bravery and style.

To assess worker agency, we must separate intentionality from effects, neither of which can be appreciated without an awareness of subjectivity. It is precisely a neglect of subjectivity, defined as "the ensemble of modes of perception, affect, thought, desire, fear, and so forth that animate acting subjects," to which Sherry Ortner (2005:3I) has drawn attention in arguing that anthropology's increasing suspicion of the explanatory value of "culture" has led to an impoverished understanding of human motivation. When garment workers thief a chance, they enact a particular interpretation of the world, structured by their cultural histories and the economic exigencies of the present. An emphasis on subjectivity helps us to move beyond the simplistic notion that choice is constrained by circumstances, to see instead that actors possess 
an internalized "sense of what is possible and what is not" (Gregory 2007:207). Thiefing a chance is the expression of an individualistic, enterprising subjectivity. I argue that its routine enactment in the workplace has not only direct consequences for the politics of labor but also the insidious effect of validating neoliberal principles of opportunism and self-seeking that make it difficult for workers to find common cause through conventional avenues of solidarity.

\section{Research Strategy and Methods}

I spent fifteen months in Trinidad, from August 2003 to November 2004. It was my first experience in the country, other than a short visit in March 2003 to assess the feasibility of my research project and seek the advice of scholars at the University of the West Indies. Inspired by Kevin Yelvington's 1995 ethnography of a Trinidadian factory and hoping to reassess its findings in light of the emerging neoliberal orthodoxies of privatization, deregulation, and liberalization, my first goal upon arrival was to find a factory where I could undertake long-term participant observation. After three weeks of contacting garment factories on my own with little success (I would be given an interview, a polite tour of the factory, and a firm "no" to my request to work as an unpaid employee), I turned for help to a friendly cloth merchant I had met during my first days in the country. He arranged for me to meet Helene Forester, a well-known fashion designer and co-owner (with her husband, Robert) of Signature Fashions, a local company with a small factory in Trinidad and nearly twenty stores in the Eastern Caribbean. With none of the suspicion and wariness I had encountered at other factories, Helene and Robert seemed amused by my proposal to trade my labor for a chance to get to know the workers.

Over the following nine months, I arrived at the factory at 7:30 a.m. each weekday (and occasional Saturdays), leaving at 3:30 or 5:30 in the evening, depending on whether overtime was required. I told the workers I met that I was an American student from a university in England and that I wanted to learn about their experiences so I could write a book about Trinidad's garment industry. Although I was initially reluctant to take notes, by the third month of research I was carrying a small notebook in the front pocket of my apron and openly scribbling in it throughout the day. I was surprised to find my jottings mostly ignored by workers, except when they felt they had been 
poorly treated and insisted I write it down in my "book." By taking notes throughout the day, I managed to record many conversations taking place in my midst nearly word for word with the speakers' knowledge. These dialogues proved to be rich data, and this book therefore has a strong emphasis on the everyday, vernacular language of the shop floor.

In transcribing forms of Trinidadian spoken English locally referred to as "dialect," I follow the convention of the national newspapers ("ehnt" for "ain' t" and "t'ing" for "thing"). Although dialect is socially devalued in official environments such as educational institutions and workplaces, it also serves as a national unifier: a point of pride, affection, and cultural difference for Trinidadians among the community of nations. Dialect is associated with the everyday speech of the working class of all ethnic backgrounds, but Trinidadians of all social classes (and indeed, ethnic groups) selectively play with dialect as a means of marking in-group relations, signaling solidarity, or satirizing themselves and others. In representing the speech of my informants, I try to capture the sound of their words as spoken, explaining meanings when they may not be apparent to readers unfamiliar with the region. In doing so, I attempt to preserve the deliberateness of my informants' linguistic choices without exoticizing the "otherness" of their speech (Mose Brown and Masi de Casanova 20I4).

After I had worked in the factory for several months, management gave me permission to conduct one recorded interview with each worker on wooden benches outdoors during slow work days. By the time of these interviews, I knew most of the workers well and already considered some to be friends. After many hours of working, shopping, talking, and "liming" (relaxed socializing) together, these interviews filled in the gaps in my knowledge and provided them with a chance to narrate their own experiences for the record. Every worker but one allowed me to tape these conversations; I also recorded interviews with management and the factory owners, as well as owners and workers at several other Trinidadian factories as part of a wider survey of the industry I conducted in the summer of 2004.

Working in a factory as a major component of fieldwork has both advantages and disadvantages in comparison to other forms of ethnographic research (Hsiung 1996; Salzinger 2003; Yelvington 1995). The primary advantage of participant observation in the factory is that it provides a sustained and intimate look at how the workplace "works," allowing the researcher to 
distinguish "people in terms of what they actually do" from "merely what they say they do" (Miller 1997:I6-I7). By internalizing the time disciplines, physical movements, and bodily postures required of workers in the industry, the researcher is able to get a deeper sense of the relationship between the factory as a material and discursive context and the factory as lived space. As an unpaid employee, I could be both witness to and subject of disciplinary power, although always in critically different ways than the other workers. The factory also provides a mundane, everyday context for meeting people and gradually establishing relationships.

Yet the disadvantages of participant observation in a factory are also legion. I found the work physically punishing, especially when I spent ten hours a day carrying, stacking, and cutting cloth during a busy period before Christmas. I pushed myself to do a "good job" on all the tasks assigned to me, not only as a sign of goodwill toward the factory owners but also because my short conversations and joking banter with workers were predicated on a shared acknowledgment that the work had to get done. After a hard day's work, I sometimes could muster only an hour of typing notes while my fellow workers were home preparing meals, cleaning their houses, sewing for private clients, and looking after children. Like many of them, I took a break each evening to watch the 6 o'clock news and The Bold and the Beautiful, an American soap opera that has eclipsed The Young and the Restless as the Trinidadian media obsession (cf. Miller 1992).

My routine movements during the week shadowed those of the workers I researched. We took early-morning route taxis together to the highway where the Signature Fashions factory was located; we shopped in Port of Spain in the evening for fresh fruit and vegetables on our way home. On Saturday mornings I bought groceries at the open market on the Beetham Highway. I spent Sundays visiting the churches and homes of Signature Fashions workers. The constricted geography of my everyday routine represents a stark contrast to the peripatetic activities of anthropologist Michael Lieber (198I), who followed his male informants across Port of Spain each day as they hustled livelihoods in the informal sector. This difference not only reveals the gendered and occupational patterns of day-to-day motility; it also indicates that although many accounts of Caribbean life emphasize open-endedness, freedom, and movement, some working-class women find it difficult to escape tightly circumscribed avenues because of the high cost 
of transportation and the arduous demands of daily work. Time for "fetes" (parties), Afro-religious feasts, and liming was carved out of the late-night hours, often at the cost of sleep. The occasional fete at a worker's home was meticulously planned, usually around a child's birthday, with a great deal of cooking and investment in rented sound equipment for music if money was available. Younger garment workers with boyfriends might be taken "out." For many of the older workers, religious worship and family gatherings seemed to be the only time when they were not engaged in incomegenerating activities, household tasks, or rest.

From the shop floor of Signature Fashions, I followed various threads that led to other research sites. I conducted short-term ethnographic research in two other workplaces: a small garment factory ("Universal Uniforms") that produced vocational and school uniforms for the Caribbean market and a Carnival mas (masquerade) camp, where I spent evenings gluing sequins on bikinis leading up to the pre-Lenten Carnival. I also learned about the industry by touring factories and repeatedly visiting the offices, homes, or workplaces of seamstresses, tailors, government officials, businesspeople, educators, and trade unionists. I visited medical clinics where occupational injuries are evaluated and treated, the homes and offices of alternative-care practitioners, and the churches and temples where many workers go to have their bodies rejuvenated and healed. Many of my relationships built during my initial fieldwork have endured over the subsequent ten years, strengthened by visits, phone calls, text messages, and sharing our lives over Facebook.

During my first six months in the field, I lived in a working women's hostel in Port of Spain, sharing a bedroom with a nineteen-year-old student from Tobago. When my partner, Michael, had saved enough money to quit his job in England and join me in Trinidad, we moved into a one-bedroom house in the working-class neighborhood of Belmont. Our house was near the homes of Donna and Jean, two Signature Fashions workers who helped me find the rental. I began taking sewing lessons three nights a week from Donny, a local tailor. I wanted to better understand how to construct a whole garment from scratch (a common skill among Signature's workers) and to gain an embodied understanding of how to select cloth, devise and cut a pattern, and sew a garment together. Learning how to sew became inseparable from fieldwork; in factories, in Donny's shop, and in garment workers' homes, sewing 
alongside others gave me precious insight into the material construction of garments and their makers' social worlds (Prentice 2008).

Living in a predominantly Afro-Trinidadian area of Port of Spain has undoubtedly shaped my account of garment workers in Trinidad, particularly as compared with the experiences of Indo-Trinidadian garment workers. Like the population of the country, approximately half of the Signature Fashions workers could be described as "Afro-Trinidadian," claiming descent primarily or exclusively from African slaves or settlers, and half could be described as "Indo-Trinidadian," claiming descent primarily or exclusively from South Asian indentured laborers. I got to know both groups well, in part, I believe, because my outsider status (white and foreign) prevented my being too quickly categorized as the "natural" ally of either group; nonetheless, most (though by no means all) of my closest informants were Afro-Trinidadian. Of course, the phrase Trinidadian garment workers refers to a diverse and internally differentiated group of people, not simply along demographic lines of race, age, marital status, area of residence, and so on, but also in regard to personal histories, habits, desires, and life projects. I specify in the text where garment worker is a useful term that captures commonalities of experience and where important differences may be found within that broad category. ${ }^{3}$ Following Viranjini Munasinghe (200I:xi-xii, 97), I use the terms Indo-Trinidadian and Afro-Trinidadian throughout my ethnography to distinguish etic analysis from everyday, emic speech: "Indian" or "East Indian" to denote Trinidadians of predominantly or entirely South Asian descent and "African," "Negro," "Black," "Creole," or "Afro-Creole" to denote Trinidadians of predominantly or entirely African descent.

Many anthropologists have noted that the intimacies of long-term ethnographic research in complex fields of power generate particular predicaments, both in the field (Brown 1987; Ulysse 2002) and during the writing process afterward (Behar and Gordon 1995; Clifford and Marcus 1986; M. Wolf 1992). A feminist orientation attuned me to multiple, shifting power dynamics in play, not only among individuals and groups in the factories but also in my own relationships with informants and friends. Anthropologists get close to informants and then write about intimate details of their lives-a situation so laden with power disparities that some scholars have questioned the viability of a "feminist ethnography" altogether (Enslin 1994). I am heartened by Judith Stacey's conclusion that although ethnography is more perilous 
than the supposedly masculinist research strategies of objective social science (wherein both researcher and researched have defined and limited roles), the "uneasy fusion" of feminism and ethnography produces critical knowledge with a subtlety and perceptiveness unachievable through other means (Stacey 1988:26), the loss of which would diminish our understanding of the world.

I have honored my promise to keep my informants anonymous by using pseudonyms for all named persons and factories in the text and, on rare occasions, subtly altering an informant's distinguishing features. In writing about illicit practices in the Signature Fashions factory, I have chosen to focus on workers who are no longer employed there. I have used similar tactics to disguise the identity of Signature Fashions, which is one of several brand-name clothing producers in Trinidad. The long lead time in academic publishing has meant that both the company and workers about whom I write have moved on in many different ways. As the Trinidadian garment industry continues to shrink and transform itself, some workers have taken up employment in other areas, such as food service. Many of the women most devoted to working "in the sewing" now operate entirely in the informal sector of own-account work; several factory owners have cut costs by closing operations and sending workers home with industrial-grade machines and sewing to complete on a piecework basis. But that is a story for another time.

\section{Assembling the Factory}

This book pivots around the organizing concept of "thiefing a chance," which here connotes Trinidadian ways of constructing a livelihood by seizing formal, informal, and illicit opportunities. I present thiefing a chance as a metaphor for life under neoliberalism, where workers are expected to be adaptive and enterprising, resilient and uncomplaining. These "flexible" economic qualities are embraced and indeed embodied by Signature Fashions workers-in part because of the exigencies of contemporary life in Trinidad and in part as a result of the historical ways Caribbean subjectivities have been shaped by capitalistic imperatives since the region's founding.

The next chapter serves as an introduction to the factory and brand at the center of this book. Anthropological studies of factory life tend to make two assumptions: that capitalists know their own interests and that they act upon them. These assumptions too often generate ethnographies 
that pit capital against labor in an interlocking struggle over interests. Here I show the factory to be a much more in-deliberate and serendipitous entity, constituted through the competing and frequently unarticulated desires of factory owners, managers, and workers. By portraying how the factory "works" both materially and socially, I reveal the productivity of the informal and the illicit and how a flexible factory might come to rely on these hidden registers of production.

Chapter 3 serves as an introduction to the Signature Fashions workers. With emphasis on the life stories of three garment workers, I show the role of emotion and pleasure-rather than just economic necessity - that draws Trinidadian women into and out of the garment industry. As highly skilled seamstresses, they often describe themselves not as "garment workers" but instead as women "into the sewing," committed to making a living through the production of clothing in factories, small workshops, or at home sewing for private clients (and often all three). This chapter introduces the workers' home communities and shows how racial identities and communities of origin shape hierarchy and authority through the classification of working bodies on the shop floor.

Chapter 4 describes illicit labor practices secretly (and not-so-secretly) performed by workers each day. These practices, which workers dub "thiefing a chance," include furtively producing extra garments on the assembly line to distribute among themselves, as well as quietly trying out new machines without managerial permission. Workers' categorical rejection of a discourse of resistance to justify "thiefing" suggests that these illicit shop-floor activities would be best interpreted within a creole cultural schema that celebrates cunning self-reliance. Thiefing as a do-it-yourself enterprise represents not a rejection of the values of neoliberalism but rather their elevation.

I describe how Trinidadian garment workers gain expertise in sewing in chapter 5 . Workers rely on their technical sewing abilities and knowledge of fashion to forge livelihoods in an unstable and demanding industry. Signature Fashions workers describe skills not as a functional capacity but instead as a cumulative project of self-actualization located in the body. I show how "love" of sewing ties together formal and informal sectors of Trinidad's garment industry yet also how the willingness of women "into the sewing" to embrace opportunity and change is exploited in contexts of waged employment. 
Chapter 6 explores how the shop floor is experienced through workers' bodies by examining how they perceive and navigate shop-floor risks of injury and ill health. The factory is an environment in which workers try to protect their bodies and maintain health by asserting control over the pace and progress of their work. These relations of "normal" exploitation are thrown into disarray by episodes of injury that become flashpoints of debate. With the post-liberalization withdrawal of state and trade-union interest in factory workers' welfare, the romantic image of workers as dynamic, flexible, and autonomous agents encapsulated in discourses of thiefing a chance is continually challenged by what Elaine Scarry (1985:I4) has called "the sheer material factness of the body."

Chapter 7 looks outward from the shop floor onto an epidemic of kidnappings for ransom that rocked Trinidad during the period of fieldwork. Garment factories were uniquely entangled in the kidnapping crisis because the owner-managers of small family enterprises were often represented in the public imaginary as prime targets for abduction by poor urban criminals, making the shop floor a site of a potentially risky mixture between antagonistic categories of people. The widespread accusation that fabric importers were smuggling drugs and guns into Trinidad interpreted the wealth of industry leaders as ill-gotten and their abduction as morally justifiable. At the Signature Fashions factory, workers and managers grappled with the notion that the neoliberal era is deeply criminal, in which financial gain is a dirty business. I also show how local critiques of the global economy can become mired in internal feuds over race and politics.

\section{Notes}

I. CARICOM countries include Antigua and Barbuda, the Bahamas (though not a common-market member), Barbados, Belize, Dominica, Grenada, Guyana, Haiti, Jamaica, Montserrat, St. Kitts and Nevis, St. Lucia, St. Vincent and the Grenadines, Suriname, and Trinidad and Tobago (Griffith 1990:50; ILO 2004).

2. An emphasis on economic and cultural continuities before and during trade liberalization in Trinidad represents an important corrective to an analytical preoccupation with the "exceptional" nature of neoliberal capitalism (Ong 2006; Sanders 2008:III). As Jamie Cross (2010a) has argued in relation to workers in India, the adverse labor conditions formalized in neoliberal enclaves such as 
export-processing zones are not very different from those long found in the informal economy outside of them.

3. As I explain in chapter 3, many Signature Fashions workers reject the label "garment worker" and describe themselves instead as women who are simply "into the sewing." For the sake of clarity, I retain the phrase garment workers to refer to the diverse group of individuals who make their living from producing garments, including women who prefer to represent themselves as "into the sewing," noting (where relevant) the importance of the distinction between the two categories. 